\title{
Evaluation of wildland fire smoke plume dynamics and aerosol load using UV scanning lidar and fire-atmosphere modelling during the Mediterranean Letia 2010 experiment
}

\author{
V. Leroy-Cancellieri ${ }^{1}$, P. Augustin ${ }^{2,4}$, J. B. Filippi ${ }^{1}$, C. Mari $^{3}$, M. Fourmentin ${ }^{2,4}$, F. Bosseur ${ }^{1}$, F. Morandini ${ }^{1}$, and \\ H. Delbarre ${ }^{2,4}$ \\ ${ }^{1}$ Laboratoire Sciences Pour l'Environnement, CNRS-Université de Corse, Corte, France \\ ${ }^{2}$ ULCO, LPCA, 59140 Dunkerque, France \\ ${ }^{3}$ Laboratoire d'Aérologie, CNRS-Université Paul Sabatier, Toulouse, France \\ ${ }^{4}$ Université Lille Nord de France, 59000 Lille, France
}

Correspondence to: V. Leroy-Cancellieri (vcancellieri@univ-corse.fr)

Received: 25 June 2013 - Published in Nat. Hazards Earth Syst. Sci. Discuss.: 8 August 2013

Revised: - Accepted: 30 December 2013 - Published: 4 March 2014

\begin{abstract}
Vegetation fires emit large amount of gases and aerosols which are detrimental to human health. Smoke exposure near and downwind of fires depends on the fire propagation, the atmospheric circulations and the burnt vegetation. A better knowledge of the interaction between wildfire and atmosphere is a primary requirement to investigate fire smoke and particle transport. The purpose of this paper is to highlight the usefulness of an UV scanning lidar to characterise the fire smoke plume and consequently validate fireatmosphere model simulations.

An instrumented burn was conducted in a Mediterranean area typical of ones frequently subject to wildfire with low dense shrubs. Using lidar measurements positioned near the experimental site, fire smoke plume was thoroughly characterised by its optical properties, edge and dynamics. These parameters were obtained by combining methods based on lidar inversion technique, wavelet edge detection and a backscatter barycentre technique. The smoke plume displacement was determined using a digital video camera coupled with the lidar.

The simulation was performed using a mesoscale atmospheric model in a large eddy simulation configuration (Meso-NH) coupled to a fire propagation physical model (ForeFire), taking into account the effect of wind, slope and fuel properties. A passive numerical scalar tracer was injected in the model at fire location to mimic the smoke plume. The simulated fire smoke plume width remained within the
\end{abstract}

edge smoke plume obtained from lidar measurements. The maximum smoke injection derived from lidar backscatter coefficients and the simulated passive tracer was around $200 \mathrm{~m}$. The vertical position of the simulated plume barycentre was systematically below the barycentre derived from the lidar backscatter coefficients due to the oversimplified properties of the passive tracer compared to real aerosol particles. Simulated speed and horizontal location of the plume compared well with the observations derived from the videography and lidar method, suggesting that fire convection and advection were correctly taken into account.

\section{Introduction}

Southern Europe and the Mediterranean basin are regularly affected by forest fires which can burn thousands of hectares in a few days. A recent publication from the European Forest Fire Information System accounts for 65000 fires which occur in Europe every year, burning half a million hectares of vegetation and forest, with $85 \%$ of the burnt area being in the European Mediterranean region (San-Miguel-Ayanz et al., 2012).

These vegetation fires emit large amount of gases and aerosols (Langmann et al., 2009), which are detrimental to human health (Wegesser et al., 2009; Franzi et al., 2011) and degrade visibility. Smoke exposure of fire fighters during fire 
operations is of particular concern (Reinhardt and Ottmar, 2004; Leonard et al., 2007). Fire experimental fields in France (Barboni et al., 2010) and Portugal (Miranda et al., 2005) have revealed concentrations of toxic air pollutants well above exposure limit values set by the European regulatory rules. Using airborne observations, Phuleria et al. (2005) and Singh et al. (2012) documented the contribution of fire emissions to the urban pollution during the Californian fires in 2003 and 2008 respectively. Elevated $\mathrm{PM}_{2.5}$ concentrations were observed by air quality ground stations tens of kilometres downwind of an arson fire in southern France (Strada et al., 2012). During the Gestosa 2002 experimental field fires in Portugal, Miranda et al. (2005) reported extreme hourly averaged particulate matter concentration of $2350 \mu \mathrm{g} \mathrm{m}^{-3}$ for $\mathrm{PM}_{2.5}$ and $1430 \mu \mathrm{g} \mathrm{m}^{-3}$ for $\mathrm{PM}_{10}$. During the last decade, considerable efforts were made to characterize the organic and inorganic compounds in the gas and particulate phases from prescribed fires (Lee et al., 2005; Yan et al., 2008; Alves et al., 2011; Burling et al., 2011) or uncontrolled fires (Alves et al., 2010; Vincente et al., 2012) in contrasted fuel and meteorological conditions. Despite these recent studies, the characterisation of the chemical compounds in smoke remains incomplete, in particular for Mediterranean fires, mainly due to the extreme difficulties in obtaining smoke samples from wildland fires.

To comply with regulatory rules, modelling tools are needed to accurately predict the contribution of fire emissions to visibility attenuation and gas and particle concentrations. Unfortunately, the ability of existing models to simulate smoke production and dispersion is currently limited by inaccurate fire emissions, uncertainties in fire behaviour and plume rise estimates (Miranda, 2004; Hodzic et al., 2007; Strada et al., 2012). In particular, it is well known that weather has a dominant role in the fire propagation, especially wind force and direction. Conversely, fire influences the dynamics and the chemistry of the atmosphere through the injection of heat fluxes and chemical compounds. Two models were developed recently which integrate the twoway interactions between fire and the surrounding atmosphere: the WRF/SFIRE model (Mandel et al., 2011) based on the former work of Clark et al. (1996) and the MesoNH-ForeFire model (Filippi et al., 2009, 2011). An accurate validation of the smoke plume rise forecast by these fireatmosphere mesoscale models for a wide range of meteorology, fire behaviour, fuel, and topography is critical. Prescribed fires, such as the one conducted in Letia (France) in 2010 and further described in Sect. 2, can help to validate these models even though the fuel conditions and meteorology significantly differ from wildfires.

In particular, this paper describes a rigorous evaluation of a fire plume rise and dispersion achieved through the comparison of the model forecast with lidar (light detection and ranging) observations of fire aerosols. Lidars measure the backscattered radiation intensity from detected aerosols in the atmosphere. Lidar observations indirectly provide a measure of smoke density distribution. The usefulness of ground-based scanning lidars to assess plume rise dynamics and height was illustrated recently by Kovalev et al. (2009), Wold et al. (2010) and Charland and Clements (2013). Utkin et al. (2003), Lavrov et al. (2006) and Fernandes et al. (2006) demonstrated the feasibility of forest-fire smoke detection using lidar even if the source is out of sight or under unfavourable visibility conditions. Matis et al. (2003) used lidar-observed backscatter and extinction coefficients, particle optical depths, extinction-to-backscatter ratios and depolarisation ratio to identify unequivocally aged smoke lidar observations from Siberian fires above Germany in spring 2003. Following a similar approach, Amiridis et al. (2012) identified highly absorbing fresh smoke particles lofted between 2 and $4 \mathrm{~km}$ with lidar measurements during the wildfires in Greece in 2003. Pahlow et al. (2005) and Kovalev et al. (2009) used lidar measurements of smoke particles as tracers for the study of the atmospheric boundary layer structure and fire injection height during a fire event. Lidar observation is therefore of prime interest not only for fire surveillance but also to derive the injection height of fire-emitted compounds.

The present paper focuses on the validation of simulated smoke injection heights and dynamics derived from a highresolution fire-atmosphere model using lidar vertical scans during a prescribed fire held in Corsica. The second section describes the experimental strategy and instrumentation deployed during the experimental fire. Section 3 is devoted to the lidar and camera instrumentation setup. This section also describes the technique to derive particle backscatter coefficient from lidar raw signals and the barycentre method applied for the comparison between lidar observations and the fire-atmosphere model. In Sect. 4, the core physical equations of the fire spread model and the coupling technique between the atmospheric and fire models are defined. In the last section, results from the Meso-NH-ForeFire coupled model are compared with the lidar observations and discussed in terms of plume injection height and dynamics.

\section{The Letia 2010 experiment}

\subsection{Site description and instrumental deployment}

The experimental burn took place on 5 November 2010 in Corsica $\left(8^{\circ} 51^{\prime} 36^{\prime \prime} \mathrm{E}, 42^{\circ} 13^{\prime} 25^{\prime \prime} \mathrm{N}\right)$, in the south of France. The site is located at an altitude of $1400 \mathrm{~m}$. It was chosen by our public partners, the French Forest Service and the Regional Natural Reserve of Corsica, since this burning joins in the problem of country planning in rural areas. The climate is typically Mediterranean with hot dry summers.

The experimental site (see Fig. 1) was $720 \mathrm{~m}^{2}$. It was a rectangle $24 \mathrm{~m}$ wide perpendicular to the slope and $30 \mathrm{~m}$ long parallel to the slope. The experiment is located in an area with a steep slope between 12.5 and $13^{\circ}$. In order to 


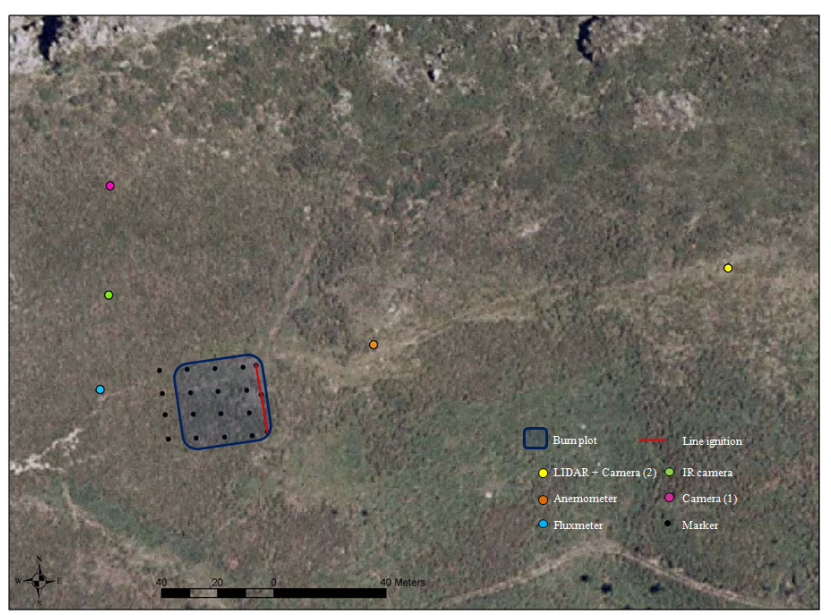

Fig. 1. Experimental site and array of devices.

preserve the integrity of the personnel but also to prevent any fire breakout, a fuel break delimits the left side and the top corresponding to the crest of the mountain. A line ignition was performed along the bottom of the slope on the entire length of the plot using a petrol torch. The fire started at 10:22 and ended at 10:37 UTC. In order to characterise the initial conditions and the behaviour of the fire, different measuring apparatus were deployed on site. The devices are depicted hereafter and displayed in Fig. 1, which presents the overall experimental setup.

\subsection{Vegetation cover}

Because not all biomass burns the same ways, a description of fuel properties is required for predicting whether a fire will be ignited, its rate of spread and its intensity. The qualitative and quantitative determinations of fuels are thus essential to serve as input data for a fire spread model. The collection of fuel properties is generally discriminated by size class and dead/live condition.

For the present experiment, fuel consisted of endemic broom (Genista salzmannii). This species is characterised by a very strong homogeneity and a $90 \%$ cover. The height varies between 30 and 60 centimetres with a mean value of $45 \mathrm{~cm}$. In this case of homogenous fuel bed, experimental measurements of the residence time of fires (which is defined as the length of time a flaming front passes a particular point) have shown that only small fuel particles $(\varphi<6 \mathrm{~mm}$ and surface-to-volume ratio $>600 \mathrm{~m}^{-1}$ ) can contribute actively to the dynamics of a wildfire (Burrows, 2001). At landscape scale, it was also assumed that thin dead fuels are mainly responsible for fire spread, considering that live fuels and coarse dead fuels are partly desiccated within the flame and not only ahead of the fire front (Santoni et al., 2011). According to these observations fuel characteristics were done for thin dead particles; this information will serve as data entrance for the combustion model and is listed in Table 1.

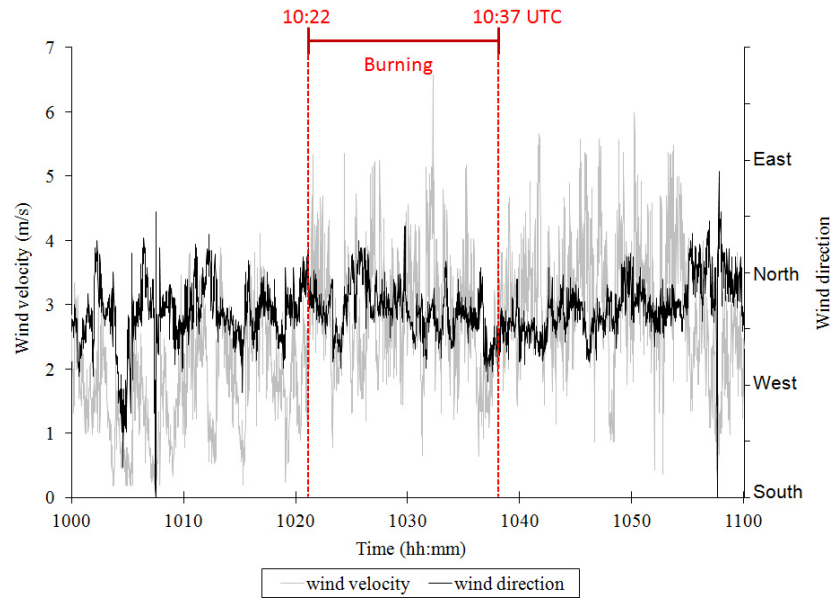

Fig. 2. Wind velocity and direction measured during the fire spread experiment.

Fuel moisture is an important parameter because it affects the proportion of flaming to smouldering and their relative combustion efficiency. Fuel moisture content on a dry basis (the ratio of the difference between the wet and oven-dried weights to the oven-dried weight) was measured for the sample collected the day of the burn and oven-dried for $24 \mathrm{~h}$ at $333 \mathrm{~K}$. In order to take into account the structural properties of the fuel, the surface-to-volume ratio and density were measured following the method proposed by Moro (2006). The day of the burn, total fuel loading (mass of fuel per unit area) was estimated through destructive sampling of a $2 \mathrm{~m} \times 2 \mathrm{~m}$ plot. The heat of combustion and specific heat content were measured in an oxygen bomb calorimeter following the standard (ASTM D2015-96 standard, 1996). The rate of heat release for the burnt fuel was $33.5 \mathrm{MJ} \mathrm{m}^{-2}$ of dead fuels.

Table 1 gathers the characteristics of the Genista salzmannii species in the burning conditions; parameters of live particles was also provided for information.

\subsection{Meteorological conditions}

The wind velocity and direction were recorded using a two-dimensional ultrasonic anemometer at $2.5 \mathrm{~m}$ above the ground surface to reflect the average wind acting on the fire front. The anemometer was located in the opposite direction of the propagation (at the foot of the plot) to minimise the influence of the fire on the wind measurements. Furthermore, such a location protected the ultrasonic transducers from smoke and large-diameter firebrands generated by the fire which can affect sonic measurements. The wind data were recorded using another (synchronised) data logger at a sampling rate of $1 \mathrm{~Hz}$ (Fig. 2). The average velocity of the wind measured during the experiment was $2.6 \mathrm{~m} \mathrm{~s}^{-1}$ and its direction was close to $\mathrm{NW}\left(328^{\circ}\right)$.

The ambient temperature, relative humidity and pressure were measured at the start of the experiment. 
Table 1. Fuel characteristics derived from laboratory measurements for Genista salzmannii collected at the experimental site in Letia.

\begin{tabular}{llcr}
\hline & & \multicolumn{2}{c}{ Genista salzmannii $(\varphi<6 \mathrm{~mm})$} \\
\cline { 3 - 4 } Parameters & Variable & Live & Dead \\
\hline Moisture content on dry basis $(\%)$ & $m$ & 66.7 & 17.9 \\
Fuel load $\left(\mathrm{kg} \mathrm{m}^{-2}\right)$ & $\omega$ & 0.997 & 0.790 \\
Heat of combustion $\left(\mathrm{kJ} \mathrm{kg}^{-1}\right)$ & $\Delta \mathrm{H}$ & 20645 & 20239 \\
Specific heat content $\left(\mathrm{J} \mathrm{kg}^{-1} \mathrm{~K}^{-1}\right)$ & $C_{p}$ & 1648 & 1922 \\
Surface to volume $\left(\mathrm{m}^{-1}\right)$ & $\sigma$ & 3100 & 2505 \\
\hline
\end{tabular}

Table 2. Meteorological conditions.

\begin{tabular}{lllll}
\hline Wind velocity $\left(\mathrm{m} \mathrm{s}^{-1}\right)$ & Wind direction $\left({ }^{\circ}\right)$ & Pressure $(\mathrm{hPa})$ & Temperature $\left({ }^{\circ} \mathrm{C}\right)$ & Air humidity $(\%)$ \\
\hline 2.6 & 328 & 867 & 21.0 & 33.1 \\
\hline
\end{tabular}

\section{Lidar and camera methods}

\subsection{Scanning lidar experimental setup}

During this experiment, a UV scanning lidar ALS 300, manufactured by the LEOSPHERE company, has been used to monitor the fire smoke plume dispersion. Indeed, eyesafe UV lidars are suitable for tropospheric aerosol studies (Royer et al., 2011) and particularly to detect smoke forest fire (Lavrov et al., 2003). The total atmospheric backscatter is much stronger in UV (Rayleigh scattering) than in the near infrared, which implies high signal-to-noise ratio in this spectral range. This lidar operates with a third harmonic of a Nd-YAG laser at $355 \mathrm{~nm}$ wavelength. The energy pulse is about $16 \mathrm{~mJ}$ with a repetition rate of $20 \mathrm{~Hz}$, and the spatial resolution is $15 \mathrm{~m}$ along each beam. This instrument was located about $170 \mathrm{~m}$ east of the experimental burning site (Fig. 1). High temporal/spatial resolution continuous monitoring is performed by successive vertical scans (range height indicator) along different azimuth angles from the burning site $\left(265^{\circ}\right)$ to the west-northwest $\left(315^{\circ}\right)$. Each vertical scan duration was about $2 \mathrm{~min}$, corresponding to an average of 50100 shots per profile (Table 3 ).

The theoretical lidar blind distance $r_{0}$ for optimal nearfield overlap is about $250 \mathrm{~m}$. In order to reduce the blind distance from the lidar, a geometrical form factor (GFF) has been deduced by using horizontal profile measurements in the direction of a south (from the burning site) homogeneous clear atmosphere area before the start of the burning (Sasano et al., 1979). The GFF, deduced experimentally, has been applied in each profile obtained during the burning period, to reduce the blind distance from $250 \mathrm{~m}$ to $105 \mathrm{~m}$.

\subsection{Lidar inversion methodology}

Under several assumptions, lidar signal can be inverted to determine aerosol optical properties. In the present work, the raw lidar electrical signal is converted to backscatter coefficients following a precise technique described below.

The raw lidar return voltage $V(r)$ at a range $r$ from the lidar is

$V\left(r \geq r_{0}\right)=\frac{K}{r^{2}} \beta(r) T_{\mathrm{M}}^{2}\left(r_{0}, r\right) T_{\mathrm{A}}^{2}\left(r_{0}, r\right)+V_{0}$,

where $T_{\mathrm{M}}$ and $T_{\mathrm{A}}$ are the molecular and the aerosol transmittance respectively, $K$ is the lidar system constant (over $\left.r_{0}\right), V_{0}$ is the offset voltage and $\beta$ is the total backscatter coefficient sum of the molecular and the aerosol backscatter coefficient $\beta_{\mathrm{M}}, \beta_{\mathrm{A}}$ respectively.

The extraction of the fire smoke optical properties (optical depth, extinction and backscatter coefficient) from lidar measurements requires the knowledge of the aerosol extinctionto-backscatter ratio called lidar ratio $\left(L_{\mathrm{R}}\right)$. This parameter depends on the shape, the size distribution and the refractive index of the aerosol. In the case of multiple scattering effects on lidar signal returns, the accuracy of the effective lidar ratio $\left(\mathrm{EL}_{\mathrm{R}}\right)$, which is the product of the single scattering lidar ratio $L_{\mathrm{R}}$ and a multiple scattering factor $\eta$ (Platt, 1981), is important to deduce correctly the backscatter coefficient of the aerosol smoke plume.

In this study, we applied a technique developed by Young (1995) to retrieve, directly from lidar measurements, the optical properties of the fire smoke plume located in a homogeneous atmosphere. This algorithm was proven its robustness to inverse the lidar equation such as demonstrated in previous studies with applications on cloud characteristics (Das et al., 2009; Di Donfrancesco et al., 2006; Winker et al., 2009), desert dust layer (Mona et al., 2012), volcano ash plume (Marenco et al., 2011) or smoke plume (Omar et al., 2009; Vadrevu et al., 2012).

The effective optical depth (EOD) $\tau^{*}$ and the aerosol transmittance $T_{\mathrm{A}}$ of the smoke plume can be deduced by linear regression between the measured lidar signal and the modelled signal (Bucholtz, 1995; Bodhaine et al., 1999) over 
Table 3. Lidar strategy measurements.

\begin{tabular}{llllll}
\hline & Time (UTC) & Zenith $\left(^{\circ}\right)$ & Azimuth $\left(^{\circ}\right)$ & Step (zenith) & No. of shoot \\
\hline Scan no. 1 & $10: 27-10: 29$ & $70-89^{\circ}$ & $265^{\circ}$ & $1^{\circ}$ & 100 \\
Scan no. 2 & $10: 30-10: 32$ & $70-89^{\circ}$ & $270^{\circ}$ & $1^{\circ}$ & 100 \\
Scan no. 3 & $10: 33-10: 35$ & $50-89^{\circ}$ & $280^{\circ}$ & $1^{\circ}$ & 50 \\
Scan no. 4 & $10: 36-10: 39$ & $30-89^{\circ}$ & $285^{\circ}$ & $1^{\circ}$ & 50 \\
Scan no. 5 & $10: 41-10: 43$ & $40-89 \circ$ & $315^{\circ}$ & $1^{\circ}$ & 50 \\
\hline
\end{tabular}

a range (from lidar) below $\left(r_{\mathrm{b}}\right)$ and above $\left(r_{\mathrm{t}}\right)$ the fire plume smoke.

$T_{\mathrm{A}}\left(r_{\mathrm{b}}, r_{\mathrm{t}}\right)=\exp \left[-\tau^{*}\left(r_{\mathrm{b}}, r_{\mathrm{t}}\right)\right]$

with

$\tau^{*}\left(r_{\mathrm{b}}, r_{\mathrm{t}}\right)=\mathrm{EL}_{\mathrm{R}} \int_{r_{\mathrm{b}}}^{r_{\mathrm{t}}} \beta_{\mathrm{A}}\left(r^{\prime}\right) \mathrm{d} r^{\prime}$.

Then the $E L_{R}$ can be determined by integrating the range corrected lidar signal $\operatorname{Pr}^{2}$ from $r_{\mathrm{b}}$ to $r_{\mathrm{t}}$. Finally, the inversion of the lidar equation in order to deduce the backscatter coefficient can be done by using the following modified Fernald equations including the effects of multiple scattering (Fernald, 1984; Young, 1995):

$\beta(r)=\frac{P(r) r^{2} \exp \left[-2\left(\mathrm{EL}_{\mathrm{R}}-8 \pi / 3\right) \int_{r_{\mathrm{c}}}^{r} \beta_{M}(z) \mathrm{d} z\right]}{C\left(r_{\mathrm{c}}\right)+2 \mathrm{EL} \mathrm{L}_{\mathrm{R}} \int_{r_{\mathrm{c}}}^{r} P(r) r^{2} \exp \left[-2\left(\mathrm{EL}_{\mathrm{R}}-8 \pi / 3\right) \int_{r_{\mathrm{c}}}^{z} \beta_{M}(s) \mathrm{d} s\right] \mathrm{d} z}$,

where

$P(r)=V(r)-V_{0}(r)$

and $C\left(r_{\mathrm{c}}\right)$ is a calibration term deduced at a sufficient clear air range $r_{\mathrm{c}}$.

\subsection{Edge plume detection from lidar}

Many different lidar techniques have been developed to detect atmospheric transition zone relying on the backscattered lidar signal (Boers and Eloranta, 1986), its first or second derivative (Flamant et al., 1997; Menut et al., 1999), its variance (Hooper and Eloranta, 1986) or fitting lidar signal techniques (Steyn et al., 1999; Kovalev et al., 2009). Methods based on the Haar wavelet transform provide robust, objective, semi-automated, efficient and flexible methods, and they are less affected by signal noise than others (Davis et al., 2000; Cohn and Angevine, 2000; Gan et al., 2011; Pal et al., 2010; Mao et al., 2013). In order to determine the smoke plume edge $\left(r_{\mathrm{b}}\right.$ and $\left.r_{\mathrm{t}}\right)$, which is characterised by heterogeneous backscattering lidar signals, we have used the Haar wavelet covariance transform method (Gamage and Hagelberg, 1993; Brooks, 2003; Baars et al.,

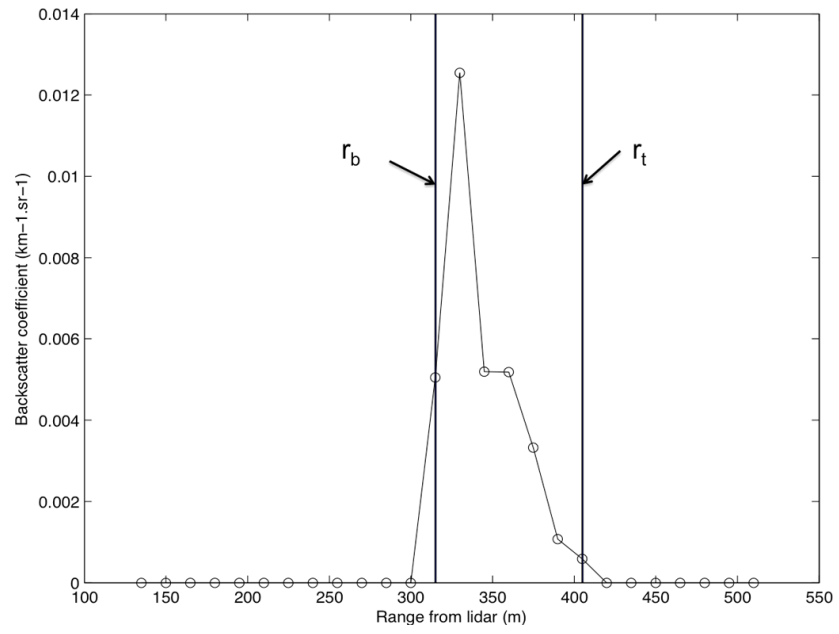

Fig. 3. Backscatter coefficient profile deduced from lidar measurements during Letia experiment. Vertical bars correspond to the smoke plume edge $\left(r_{\mathrm{b}}\right.$ and $\left.r_{\mathrm{t}}\right)$ from the lidar.

2008). This method is well suited to identify the locations of coherent transition zone between clear atmosphere and the smoke plume edge (Fig. 3).

The Haar wavelet is defined as

$H \frac{(r-b)}{a}=\left\{\begin{array}{l}-1 \Rightarrow b-\frac{a}{2} \leq r \leq b \\ 1 \Rightarrow b<r \leq b+\frac{a}{2} \\ 0 \Rightarrow \text { otherwise }\end{array}\right.$

where $a$ and $b$ are the dilation and translation coefficients of the Haar wavelet respectively. The covariance transform $W_{f}$ is defined as the convolution between the logarithm rangecorrected lidar signal $S(r)$ and the Haar wavelet $H$ :

$W_{f}(a, b)=\frac{1}{a} \int_{r_{0}}^{r}\left\{S\left(r^{\prime}\right) H\left(\frac{r^{\prime}-b}{a}\right)\right\} \mathrm{d} r^{\prime}$,

where

$S(r)=\ln \left\{P(r) r^{2}\right\}$.

Locations of the local maxima and minima of the covariance transform are identified as a transition zone of various atmospheric structures. For a well-selected dilatation coefficient, the $W_{f}$ maximum and minimum values correspond to the smoke plume edge crossed by the laser beam. 
During the experimental period, the maximum of the wavelet variance, defined as $D^{2}$ by Gamage and Hagelberg (1993), can be used to deduce the well dilatation coefficient to determine the dominant atmospheric structure in the lidar signal (Davis et al., 2000) which corresponds, in our case, to the scale of the plume structure.

$$
D^{2}(a)=\int_{r_{0}}^{r}\left[W_{f}(a, b)\right]^{2} \mathrm{~d} b .
$$

This method has been applied on each profile of all vertical scans obtained during the Letia experiment to obtain the bottom and top of the fire smoke plume.

\subsection{Fire smoke plume location from barycentre method}

Ideally, information about the location of the smoke plume or its inclination angle from the emission site can be estimated with the aerosol concentration. This approach was not possible in the present work for two reasons. The current version of the fire-atmosphere model only simulates the emission and transport of a passive tracer with no hypothesis on initial mass or size to mimic aerosols. Second, in order to derive aerosol mass concentrations from the lidar signal, additional variables have to be observed simultaneously. Raut and Chazette (2009) retrieved, from lidar and in situ optical aerosol measurements, an empirical linear method, which relates the aerosol mass concentration and the extinction coefficient. To achieve this kind of conversion, in situ additional information (scattering coefficients, aerosol size distribution or mass concentration) are thus needed. Another approach was proposed by Lavrov et al. (2006), who used the measured profiles of extinction and backscatter coefficients in a fire plume to derive the aerosol mass concentration, assuming that the aerosol mass was proportional to these optical properties. Unfortunately, a high-quality estimation of aerosol concentration from extinction or backscatter profiles cannot be obtained only with a single wavelength lidar. Previous studies have shown relationships between aerosol mass concentrations and optical thickness but in distinct environments and sources (Shinozuka et al., 2007; Chu et al., 2003; Wang and Christopher, 2003; Van Donkelaar et al., 2006) which cannot be applied directly to fire emissions.

Thus, we have used a method based on the calculation of a barycentre $\mathrm{G}$ of a fire smoke plume of $\mathrm{n}$ points weighted by backscatter coefficient $\beta_{i}$ (deduced directly from lidar measurements) with coordinates $r_{i}$, to study the dynamics of the smoke plume. The average of the weighted position coordinates of the backscatter distribution in space corresponds to the coordinates of the barycentre. In our case, the smoke plume backscatter barycentre location can be calculated by the following equation:
$\overrightarrow{\mathrm{OG}}=\frac{\sum_{i=1}^{n} \vec{r}_{i} \beta_{i}}{\sum_{i=1}^{n} \beta_{i}}$.

Moreover, the smoke plume inclination angle can be deduced, from this method, as the angle between the horizontal plane of the experimental site and the source to the barycentre coordinates' straight line. Therefore, the smoke plume backscatter barycentre of each scan lidar can be compared with the smoke plume passive tracer concentration barycentre from model outputs.

The major limitation of this comparison method is that unlike the backscatter barycentre derived from lidar observations, the concentration barycentre deduced from the simulation does not take into account the aging of gases and aerosols from the emission source through nucleation or condensation processes.

\subsection{Smoke plume displacement from videography method}

A digital video camera, located next to the lidar and oriented toward the fire field site ( 25 images per second), has been used to estimate the smoke plume displacement by combining with the lidar measurement (Weibring et al., 1998). Firstly, each sample selected from the video camera original image, corresponding to the plume structure, has been handled in order to extract the sky background by using a reference image without smoke plume. Secondly, a high Fourier frequency filter process has been applied to enhance the edge's plume structure in the spatial domain and to remove residual background noise. Thirdly, highest cross-correlation values of the images taken at time $t$ and $t+\mathrm{d} t$, corresponding to the combination of horizontal and vertical pixel displacements, have been selected during the burning period. Lastly, the horizontal pixel displacements are converted into true displacement and are corrected from the scaling effects of the distance between the plume and the camera (Weibring et al., 1998).

\section{Fire-atmosphere coupled model}

\subsection{Model description}

This section describes the numerical coupling between an atmospheric mesoscale model (Meso-NH) and a fire propagation model (ForeFire) used to reproduce the complex fireatmosphere interactions (Filippi et al., 2009, 2011). Most fire models takes into account the effects of the atmosphere (wind, humidity) on fire behaviour. We have used the theoretical 3-D physical model of Balbi et al. (2009) for the propagation velocity in the ForeFire simulation code. Feedback 
from the fire to the atmosphere is taken into account by injecting water vapour and heat fluxes in the Meso-NH model.

\subsubsection{Meso-NH atmospheric model}

Meso-NH is an anelastic non-hydrostatic mesoscale model (Lafore et al., 1998), intended to be applicable to all scales ranging from regional to micro scales, and can be coupled with an online atmospheric chemistry module. Primary meteorological variables (pressure, velocity and temperature) are advected with a centred 4th-order scheme, while scalars and other meteorological variables (such as water vapour fraction) are advected with a so-called monotonic piecewise parabolic method (Colella and Woodward, 1984). Temporal derivatives are computed following the so-called leapfrog algorithm. In this study Meso-NH is run in large eddy simulation configuration as the typical size of structures that we need to solve is less than a hundred metres (Filippi et al., 2009).

\subsubsection{Fire propagation model and simulator}

The propagation model for the fire front is based on the assumption that the front propagates in the normal direction to the front. To obtain an analytical formulation for the rate of spread, the fire is considered as the sum of a "conductive" part (vegetation under pyrolysis) and a flame heating the vegetation in front of it (Balbi et al., 2009). The model accounts for slope, atmospheric properties (wind velocity $\boldsymbol{v}$, air density $\rho_{\mathrm{a}}$ and temperature $T_{\mathrm{a}}$ ), spatial characterisation of the fuels (mass loading $\sigma$, height $e$, emissivity $\varepsilon_{v}$ and moisture content $m$ (fraction of water over total weight)) and the fuel combustion properties (ignition temperature $T_{\mathrm{i}}$, calorific capacity $c_{p, v}$, combustion enthalpy $\Delta h$, stoichiometry $s$ and mass exchange rate due to pyrolysis $\dot{\sigma}$ ). It is assumed that only a given portion $\chi_{0}$ of the total combustion energy is released as radiation, and that the flame can be modelled as a tilted radiant panel with 2 parameters: flame tilt angle towards the unburnt fuel $\gamma$ and front depth $\lambda$. The equation governing the propagation velocity of the front reads (Balbi et al., 2009)

$R=R_{0}\left(\varepsilon_{v}, T_{\mathrm{i}}, e, \sigma, m, T_{\mathrm{a}}\right)+\chi_{0} \Delta h \dot{\sigma} f(\lambda, \gamma)$,

where $R_{0}$ is the contribution of the vegetation undergoing pyrolysis ( $B$ is the Boltzmann constant and $\Delta h_{\mathrm{w}}$ the water evaporation enthalpy):

$R_{0}=\varepsilon_{v} B T_{i}^{4} e / 2 \sigma\left[c_{p, v}\left(T_{\mathrm{i}}-T_{\mathrm{a}}\right)+m \Delta h_{\mathrm{w}}\right]$.

The second term accounts for the propagation by radiation and reads

$f(\lambda, \gamma)=\frac{\lambda}{2+\mu \lambda \cos \gamma}(1+\sin \gamma-\cos \gamma)(\gamma)$,

where $\mathfrak{H}_{\mathbb{R}^{+}}$is the Heaviside function for positive reals and $\mu$ is a coefficient stemming from the model of evolution of the ratio of radiated energy versus combustion energy released with the volume-to-surface ratio (Balbi et al., 2009). The flame tilt angle depends on the slope angle $\alpha$ and wind $\boldsymbol{v}$ as follows: $\tan \gamma=\tan \alpha+\rho_{a}(\boldsymbol{v} \cdot \boldsymbol{n}) / 2(1+s) \dot{\sigma}$, with $\boldsymbol{n}$ the normal to the front. The front tracking is carried out through a discretization in a Lagrangian manner. The front is discretized as an ordered list of markers; i.e. each marker has the knowledge of its neighbours, defined by convention in the clockwise direction. The outward normal $\boldsymbol{n}_{i}$ of marker $i$ defines the direction of propagation, and $r_{i}$ the local rate of spread. One has to choose the maximum distance $p_{r}$ allowed between two consecutive markers called the perimeter resolution. If two markers are farther than this distance, a remapping of the front is carried out in order to keep the resolution constant. A filtering distance $d_{f}=p_{r} / 2$ is also needed to avoid over-crossing of two markers and potential inversion of the normal.

The advection scheme is an Euler first-order integration in space:

$\boldsymbol{x}_{i}^{(n+1)}=\boldsymbol{x}_{i}^{(n)}+\delta l \cdot \boldsymbol{x}_{i}^{(n)}$,

$t_{i}^{(n+1)}=t_{i}^{(n)}+\frac{\delta l}{r_{i}^{(n)}}$,

where the superscripts $\varphi^{(n)}$ and $\varphi^{(n+1)}$ denote the value of the variable at the next state (for our algorithm at the next spacestep) and the subscript $\varphi_{i}$ the number of the marker. The spatial increment $\delta l$ determines the resolution in the propagation of the fire front and should be smaller than the smallest space scale influencing the fire propagation, which are usually fire breaks such as roads, i.e. in typical simulations $\delta l \approx 0.1 \mathrm{~m}$.

\subsubsection{Coupling atmospheric and wildfire models}

Forcing of the atmosphere on the fire behaviour reduces to compute the wind at flame mid-height. We use a bi-linear interpolation in space and time with the ground wind issued by the atmospheric model.

Forcing the atmospheric model with ground conditions stemming from the fire is somewhat more difficult but elegant as Meso-NH is able to treat fluxes at ground level. As a mesoscale atmospheric model, there is a clear limitation to the level of the combustion process that can be resolved. The atmospheric model is not designed for cells smaller than a few metres, and the combustion model is therefore handled as a subgrid process, unlike other codes such as WFDS or FIRETEC. Despite these limitations, using a mesoscale atmospheric model is mandatory to simulate large wildfires (that can extend several tens of kilometres) as more refined models cannot handle such large domains. The forcing mechanisms imposed by the fire on the atmosphere are then treated as ground fluxes to the atmospheric simulation.

Discussions on the relevant forcing mechanisms are beyond the scope of this article. The authors chose to limit 
themselves to the ones usually considered in the literature (Kochanski et al., 2011) ,i.e. heat and water vapour fluxes. The modelling of these fluxes can be tricky, as they should represent several physical phenomena such as vegetation drying by radiation, pyrolysis and soot production by combustion. All these effects are modelled within ForeFire to provide the best boundary conditions to the atmospheric model.

Computation of the desired fluxes is carried out using a high-resolution arrival time matrix that is updated locally each time a marker is moved. Burning area is determined at each atmospheric time step and for each ground atmospheric cell as the difference between current time $t$ and arrival time of the fire at the location $t^{\mathrm{a}}(x)$. Integration of local fluxes is performed by applying a flux model $\Phi$ on all the burning map cells $I_{\mathrm{c}}$ contained in an atmospheric cell:

$\Phi^{\mathrm{atmo}}(t)=\int_{\mathrm{Ic}}^{\Phi(x, t)} ;$

thus the resolution of the burning map $\Delta x^{\text {at }}$ has to be much higher than the atmospheric cell to insure that averages over each atmospheric ground cell define well-posed boundary conditions forced by the fire on the atmosphere. Flux models for heat $\Phi_{\mathrm{h}}$ and water $\Phi_{\mathrm{w}}$ were defined as a constant release during a flaming duration $\tau$ :

$\Phi_{\mathrm{h}}(x, t)=\frac{\Phi_{\mathrm{h}}^{t}}{\tau} \Pi_{[0,1]}\left(\frac{t-t^{\mathrm{a}}(x)}{\tau}\right)$

$\Phi_{\mathrm{w}}(x, t)=\frac{\Phi_{\mathrm{w}}^{t}}{\tau} \Pi_{[0,1]}\left(\frac{t-t^{\mathrm{a}}(x)}{\tau}\right)$,

with $\Pi_{[0,1]}$ the gate function on time interval $[0,1], \Phi_{\mathrm{h}}^{t}$ the total heat to be released and $\Phi_{\mathrm{w}}^{t}$ the total water mass to be vaporised.

\subsection{Simulation setup}

The fuel is assumed to be homogeneous over the burning area, and the parameterisation used in the velocity model (from Anderson, 1969) resulted in a flaming duration $\tau=$ $24 \mathrm{~s}$. Ignition temperature is taken as $T_{i}=600 \mathrm{~K}$, water evaporation enthalpy is taken as $\Delta h_{\mathrm{w}}=2.3 \times 10^{6} \mathrm{~J} \mathrm{~kg}^{-1}$ and combustion enthalpy as $\Delta h=20 \times 10^{6} \mathrm{~J} \mathrm{~kg}^{-1}$. Heat and vapour fluxes (resp. $\Phi_{\mathrm{h}}$ and $\Phi_{\mathrm{v}}$ ) used throughout the domain are considered to constantly release heat and water vapour during the burning process over the flaming area. The total amount released during this process is induced from several assumptions. The fraction of radiant energy and combustion efficiency (portion of flaming energy useful for convection) are assumed to take values $\chi_{0}=0.30(30 \%)$ and $E_{c}=0.5$ $(50 \%)$. Moisture content was approximately $18 \%$ on the dead fuel at the time of the burn, so the total water mass to

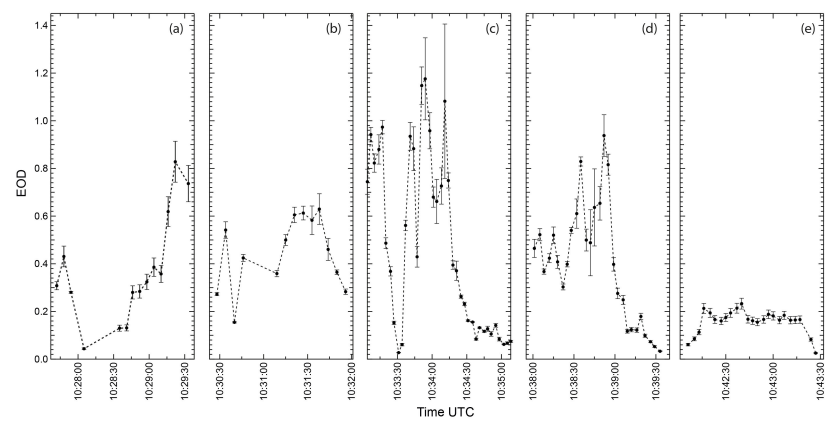

Fig. 4. Time evolution of the fire smoke plume effective optical depth (EOD) deduced from (a) scan 1, (b) scan 2, (c) scan 3, (d) scan 4, and (e) scan 5 .

be vaporised is $0.14 \mathrm{~kg} \mathrm{~m}^{-2}$. Dry fuel load was measured at $0.79 \mathrm{~kg} \mathrm{~m}^{-2}$, giving a potential energy of $15.8 \times 10^{6} \mathrm{~J} \mathrm{~m}^{-2}$, of which $0.32 \times 10^{6} \mathrm{~J} \mathrm{~m}^{-2}$ is lost to water evaporation and $30 \%$ is lost in radiation, resulting in $10.7 \times 10^{6} \mathrm{~J} \mathrm{~m}^{-2}$ of available energy. With an efficiency at 0.5 this gives a total heat release forced at ground level of $\Phi_{\mathrm{w}}^{t}=5350 \mathrm{~kJ} \mathrm{~m}^{-2}$ (with $\tau=24 \mathrm{~s}$ this gives a nominal heat fluxes of $222 \mathrm{KW} \mathrm{m}^{-2}$ ). At $10 \mathrm{~m}$ resolution, typical burning area of the fire front is about $70 \%$ of an atmospheric cell, resulting in actual typical heat fluxes of $155 \mathrm{KW} \mathrm{m}^{-2}$ forced in the ground level of the atmospheric model.

The simulation domain was designed to incorporate the dimensions of the Letia experiment using a $1280 \mathrm{~m}$-large, $1280 \mathrm{~m}$-long, $3681 \mathrm{~m}$-high box at $\Delta x=\Delta y=10 \mathrm{~m}$ resolution nested in a $10240 \mathrm{~m}$-large, $10240 \mathrm{~m}$-long, $3681 \mathrm{~m}$-high box at $\Delta x=\Delta y=40 \mathrm{~m}$ resolution initialised with analysis gathered from the Aladin Limited Area Model at 12:00 UTC. Atmospheric vertical resolution, and more precisely the elevation of the first cell $\Delta z^{g}$, impacts the dynamics of the simulation heavily as the fire is mostly a subcell phenomena modelled at ground level (from the atmospheric point of view), and thus injected fluxes in a better-resolved simulation produce larger responses from the atmospheric model.

The fire propagation resolution is $\delta l=0.02 \mathrm{~m}$, filtering distance $p_{r}=0.5 \mathrm{~m}$ and $\Delta x^{\text {at }}=0.05 \mathrm{~m}$.

Because of the scale of the experiment, observations of the precise characterisation of the fuel quantity and speed of ignition of the initial fire line were limited. Fire was ignited by crew members with torches. In the simulation, the ignition procedure has been forced by imposing a $1 \mathrm{~m}$ wide hexagon ignited from the ignition location.

Total computational time was 96000 s for the highresolution run. The fraction of CPU time that is used by the forest fire simulation is $4400 \mathrm{~s}(5 \%)$. 

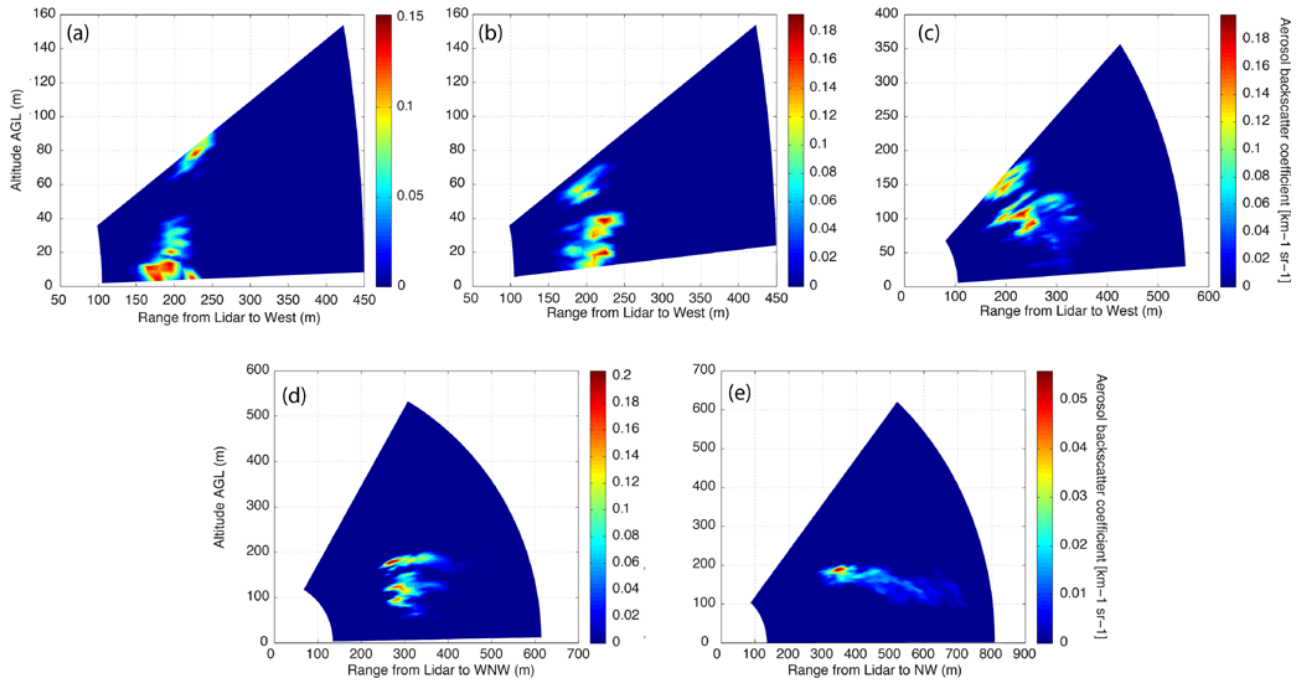

Fig. 5. Vertical cross-section of backscatter coefficient along azimuth (a) 265 at 10:27-10:29 UTC (scan 1), (b) 270 at 10:30-10:32 UTC (scan 2), (c) $280^{\circ}$ at 10:33-10:35 UTC (scan 3), (d) $285^{\circ}$ at 10:36-10:39 UTC (scan 4), and (e) $315^{\circ}$ at 10:41-10:43 UTC (scan 5).

\section{Results and discussion}

\subsection{Fire smoke plume optical properties}

During this experiment, five vertical scans were performed consecutively along different azimuth angles from the burning site to west-northwest. The fire smoke plume EOD of each slant profile was extracted and plotted separately by each scan in Fig. 4. The temporal evolution of the smoke plume EOD spreads widely from $0.03 \pm 10^{-3}$ up to $1.17 \pm$ 0.17 , and more particularly during scan 3 , which exhibits some disparate peaks around 1. High values of EOD (0.5$0.8)$ are observed in the second half period of scan 1 and scan 2, corresponding to the lower part of the vertical scans located near the ground. In contrast, during scan 3 and 4, they are, mainly, detected in the first half period of the scan duration. Furthermore they decreased both from about 1 down to 0.03 , whereas during the middle of the scan 5 duration the EOD varies slightly $(0.15-0.23)$. One can easily distinguish the increase and the decrease of the EOD, which are associated with the inner and outer edge portion of the smoke plume.

The $E L_{R}$ average smoke plume value of all scans is $79 \mathrm{Sr}$ with a standard deviation of $19 \mathrm{Sr}$ and a median of $75 \mathrm{Sr}$. The $\mathrm{EL}_{\mathrm{R}}$ range mean values obtained during each scan vary between $68 \mathrm{Sr}$ (scan 5) and $101 \mathrm{Sr}$ (scan 1). The high $\mathrm{EL}_{\mathrm{R}}$ values are mainly, more particularly, observed near the source site and may reveal the absorption nature of the fresh smoke aerosols. This $E L_{R}$ range, obtained at $355 \mathrm{~nm}$ wavelength, is in agreement with the lidar ratio $\left(L_{\mathrm{R}}\right)$ measured from a Raman lidar during DABEX (Heese and Wiegner, 2008), 2009 Attica wildfires (Amiridis et al., 2012) and during smoke plume advection from biomass burning regions over Thessaloniki in Greece (Amiridis et al., 2009). Moreover, the
$E_{R}$ values retrieved during the Letia experiment are in the range of the $L_{\mathrm{R}}$ of biomass burning aerosols deduced during the winter campaign SAMUM 2 at Cape Verde (Tesche et al., 2011; Gross et al., 2011). Therefore the EL ${ }_{R}$ Letia experiment values, corresponding to a pure biomass burning smoke, may indicate low effects of the multiple scattering inside the smoke plume.

The knowledge of $\mathrm{EL}_{\mathrm{R}}$ for each slant profile allows us to inverse correctly the lidar equation with the aim of extracting the backscatter coefficient. Vertical aerosol backscatter coefficient cross-sections (Fig. 5) clearly show heterogeneous spatial distribution of backscatter coefficient inside the fire smoke plume. Despite the fact that the duration of each scan was about 2 min, Fig. 6, which represents actual photographs of the smoke plume obtained from the lidar site during the burning period, confirms well the heterogeneous aspect of the plume. Although some scans do not detect the full smoke plume, it is possible to distinguish the core and the plume rise on most scans. In the beginning of the burning, the plume rises up to about $60-80 \mathrm{~m}$ height (Fig. 5a and b). Maximum backscatter coefficients of scan $1\left(>0.1 \mathrm{~km}^{-1} \mathrm{sr}^{-1}\right)$ are mainly located in the lower part of the plume rise near the ground at about $200 \mathrm{~m}$ range from the lidar (Fig. 5a), and during scan 2 one can see the core of the plume, associated with high backscatter coefficients $\left(>0.15 \mathrm{~km}^{-1} \mathrm{sr}^{-1}\right)$ located between 20 and $40 \mathrm{~m}$ height. Then, $10-12 \mathrm{~min}$ later (Fig. 5c and d), scans 3 and 4 reveal an increase of the backscatter coefficients in the upper part of the plume, reaching $0.19 \mathrm{~km}^{-1} \mathrm{sr}^{-1}$ at the height of $100 \mathrm{~m}$ in scan 3 and $180 \mathrm{~m}$ in scan 4 (Fig. 5c and d). During scan 4, a transition phase between the rising smoke plume domination period and the max plume height period seems to be perceptible. The smoke plume is decoupled (vertically) from the ground and the smoke injection height appears at about $200 \mathrm{~m}$ and remains 

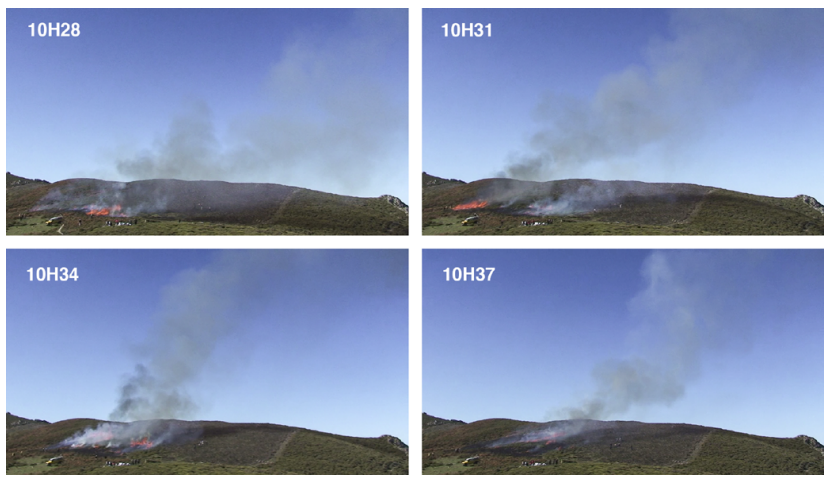

Fig. 6. Actual photographs of the smoke plume at different steps of the burning experiment.

the same in the next scan (Fig. 5e). Finally, 15 min after scan 1 , the plume is detected at about $300 \mathrm{~m}$ range from the lidar and between $100 \mathrm{~m}$ and $200 \mathrm{~m}$ above the altitude of the lidar. The maximum backscatter values observed decreases of about $0.1 \mathrm{~km}^{-1} \mathrm{sr}^{-1}$. Although this scan was accomplished after the burning period, this strong relative backscatter coefficient decrease is probably due to a weaker plume buoyancy due to entrainment of ambient air downwind.

\subsection{Simulation results and correlation with lidar observations}

In order to assess the ability of the model to reproduce the fire smoke plume characteristics (density and dynamics), a passive numerical scalar tracer was injected at the first atmospheric model level with a surface concentration of $1 \mathrm{~s}^{-1} \mathrm{~m}^{-2}$ wherever the fire is active (flaming).

Figure 7 illustrates the design of this simulation, with an overview of the simulated smoke plume mesh size and extent in the two model domains at $10 \mathrm{~m}$ (inner domain) and $40 \mathrm{~m}$ (outer domain) resolutions. We can note the simulated lidar location at the centre of the domain as well as the local vegetation visible from the aerial picture remapped to the local terrain. The lower model resolution in the outer domain does not allow resolving turbulent structures with critical length smaller than $40 \mathrm{~m}$ and shorter than a few seconds in duration.

It is worth noting that the passive tracer is appropriate to estimate the dynamics of the fire emissions, but it does not directly relate to the optical properties of the fire plume (opacity). Due to this limitation, the characteristics of the observed and simulated smoke plumes are discussed in terms of smoke plume edge (Sect. 3.3), vertical and horizontal smoke plume location (Sects. 3.2 and 3.4) and plume inclination angle (Sect. 3.4)

Figure 8 represents simulated vertical cross-section (diagnosed from the same location and time as lidar scans shots in Fig. 5) of passive tracer concentration. Experimental smoke plume edge (red star) has been superimposed on the simulated vertical cross-section. In most cases, the model was able

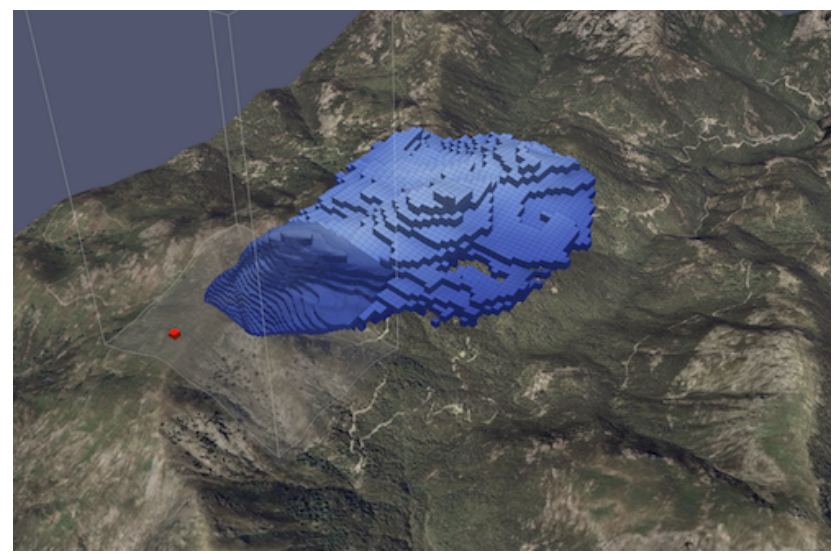

Fig. 7. Simulated smoke tracer in the large and nested domain at $t: 1000$ s. Lidar location is shown in red.

to capture the local fire smoke plume which is well located within the edge of the observed smoke plume, deduced from the lidar, more particularly during the first two scans. A slight shift of about $50 \mathrm{~m}$ to the E/ESE of the smoke bottom part is found in scans 3 and 4, whereas in the smoke plume upper layer the simulated passive tracer concentration spreads continuously outside the experimental edge plume in the W/WNW direction but with low values ( $<1.5$ a.u.). During scan 3, the upper part plume dispersion directions along the axis E-W seem to be opposite probably due to the effect of turbulence. In scans 3 and 4, the simulated injection height of the passive tracer underestimates the observed smoke plume altitude shown in Fig. 5. During the three last scans, the observed smoke plume is decoupled from the ground, which is not reproduced by the model. The smoke tracer is injected continuously at the ground level and the model does not account for chemical or physical loss terms (deposition, nucleation or condensation of particles, etc.). The passive tracer is therefore maximum at the surface, decreasing with altitude. The observed smoke plume is sensitive to high-opacity particles which tend to form at lower temperatures, i.e at higher altitude in the plume. Nevertheless, the simulated smoke injection height and smoke plume edge of the last scans appears to agree well with the observations (at about $200 \mathrm{~m}$ ).

The main location of the smoke plume density estimated by the backscatter coefficient barycentre for the observation (red circle) and the passive tracer concentration barycentre for the model (black circle) has been plotted on the simulated scans in Fig. 8 and synthesised in Fig. 9. At the beginning of the burning (scan 1 and 2), experimental and modelled barycentres are well located with only a slight difference height of $15 \mathrm{~m}$. This difference increases in the two next scans $(50 \mathrm{~m}$ and $70 \mathrm{~m})$, corresponding to a plume inclination angle difference (observation/model) of $24^{\circ}$ and $22^{\circ}$ instead of $14^{\circ}$ and $10^{\circ}$ in scan 1 and 2 . The model systematically underestimates the height of the barycentre in scan 3 and 4; this difference decreases in the last scan 5. This 

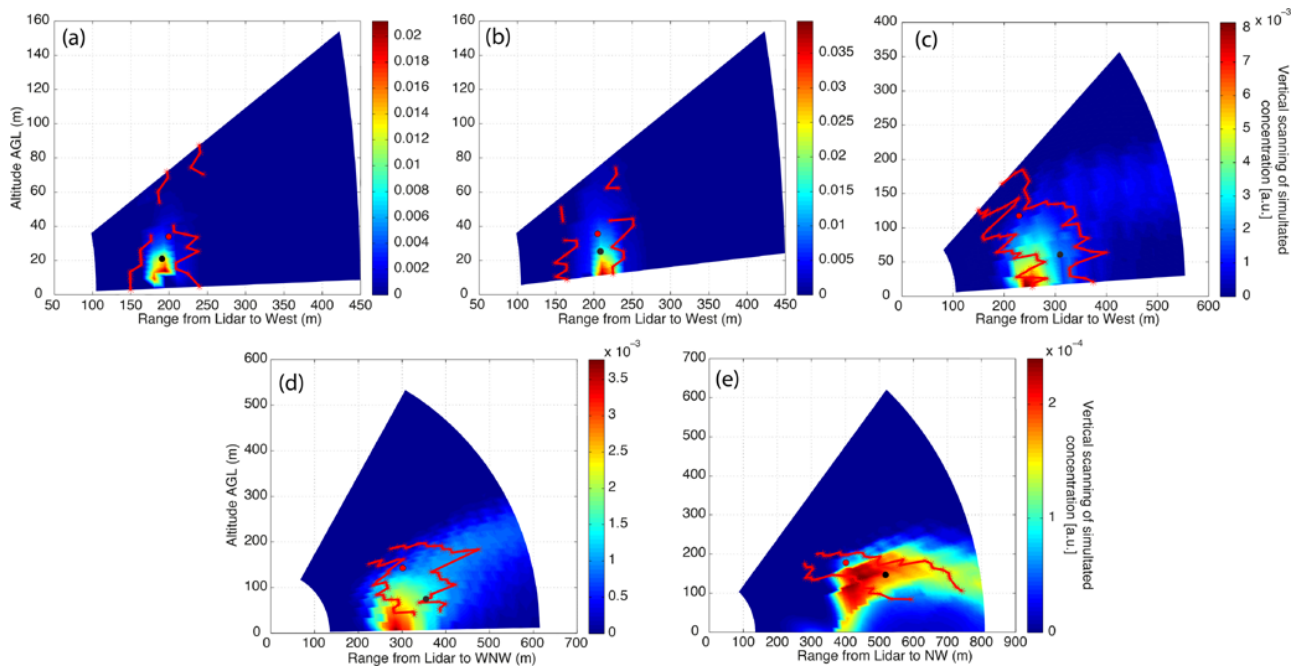

Fig. 8. As Fig. 5 but for the simulated passive tracer concentration. Observed smoke plume edge (red star), experimental (red circle) and simulated (black circle) barycentres are superimposed on the simulated passive tracer concentration vertical cross-sections.

underestimation of the simulated injection height could be partially explained not only by higher passive tracer concentration injection near the ground but also by a slight overestimation of the simulated horizontal wind speed compared to the observed wind speed derived from the videography method. Nevertheless, except during scan 3, experimental and simulated horizontal wind speeds during the burning period are in agreement (Fig. 10). The simulation has been initialised with 12:00 UTC meteorological analysis from the operational Aladin LAM at $2.4 \mathrm{~km}$ resolution. These analyses prove to be in very good accordance with the observed conditions of the day, with a slightly more westerly direction but correct wind speed according to the anemometer. Given the mountainous region it is expected that the LAM cannot represent precisely the surface flows in such steep orography. However, the model simulates correctly the smoke plume advection with a maximum deviation, between both barycentre locations (observation/model), of about $100 \mathrm{~m}$, which corresponds to a relative deviation of about $20 \%$ from the burning site (Fig. 11).

\section{Conclusions}

An instrumented field experimental burn was performed in the mountainous Mediterranean region of Letia, Corsica, a typical great wildfire danger area. The burnt vegetation was characterised by homogeneously distributed low shrubs with a heat release estimated at $33.5 \mathrm{MJ} \mathrm{m}^{-2}$ of dead fuels.

An UV scanning lidar was deployed at a range of $170 \mathrm{~m}$ from the burning site to assess the temporal and spatial evolution and injection height of the smoke plume. Aerosol optical properties and the fire smoke plume edge and main locations were derived from a combination of methods based on lidar inversion technique, wavelet edge detection method and a

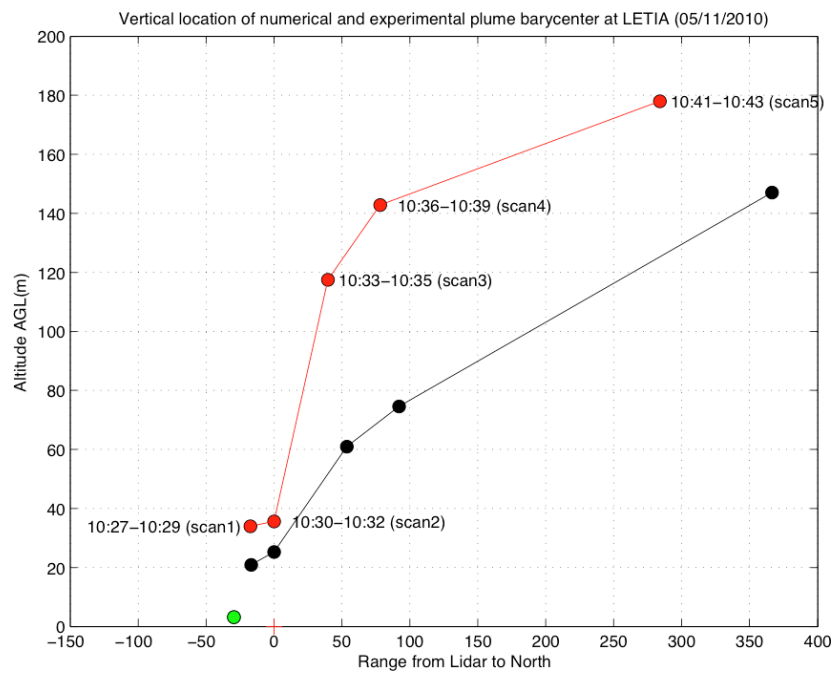

Fig. 9. Vertical locations of experimental (red circle) and simulated (black circle) barycentres; red cross and green circle symbolise lidar burning site positions.

backscatter barycentre technique. A digital video camera was coupled with the lidar measurements to estimate the smoke plume displacement. The effective optical depth (EOD) temporal evolution of the smoke plume varies from $0.03 \pm 10^{-3}$ up to $1.17 \pm 0.17$, and the effective lidar ratio $\left(\mathrm{EL}_{\mathrm{R}}\right)$ average smoke plume estimate is $79 \mathrm{Sr}$ with a standard deviation of $19 \mathrm{Sr}$ and a median of $75 \mathrm{Sr}$. Inside the fire smoke plume, backscatter coefficient spatial distribution is heterogeneous with a maximum of $0.19 \mathrm{~km}^{-1} \mathrm{sr}^{-1}$ observed $10 \mathrm{~min}$ after the burning start. The maximum smoke injection height derived from the lidar observation reaches about $200 \mathrm{~m}$. Lidar observations revealed that the smoke plume when identified by 


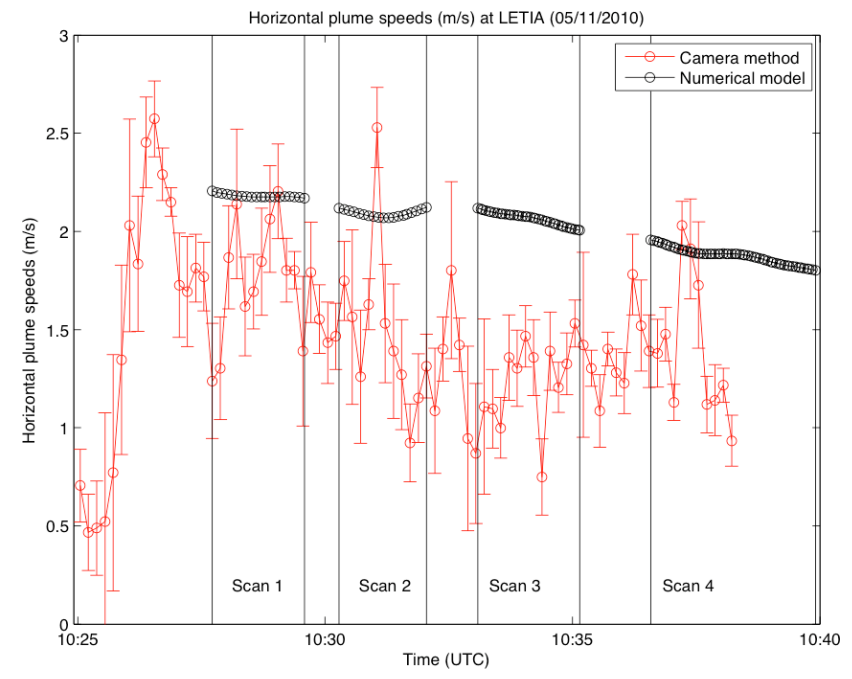

Fig. 10. Experimental (red circle) and simulated (black circle) horizontal plume speeds.

the backscatter coefficients, representative of smoke opacity, is rapidly disconnected from the ground. A fire-atmosphere model Meso-NH-ForeFire was used to simulate the experimental burn and the smoke plume at high resolution. The fire propagation was simulated with a simplified 3-D fully physical fire model based on a high-resolution front advection approach. The fire front velocity model was parameterised with the actual properties of the fuel on the burn day. The fire propagation model was coupled with the mesoscale anelastic meteorological model Meso-NH. The numerical setup consisted of 2 nested domains, at $10 \mathrm{~m}$ high resolution near the fire and $40 \mathrm{~m}$ resolution over a $10 \mathrm{~km}$ by $10 \mathrm{~km}$ area. A passive tracer was injected at the fire location to mimic the smoke plume in the model. Simulated plume width showed good agreement with the lidar observations. Simulated smoke plume top location remained within $60 \mathrm{~m}$ of the altitude derived from the lidar observations. The simulated smoke plume remained in contact with the surface due to continuous emission and missing loss processes, such as deposition or particles aging. Simulated wind speed over the fire plume compared well with the wind speed derived from the videography method, suggesting that fire convection was correctly taken into account.

This paper demonstrated the benefit of lidar observations of smoke plume for the validation of fire-atmosphere models. Further work is needed to properly simulated pyrogenic aerosols in the coupled model in order to take full advantage of the lidar measurements and increase our capacity to derive smoke exposure and associated health effects.

Acknowledgements. This research is supported by the Agence Nationale de la Recherche, IDEA ANR-09-COSI-006, http://anridea.univ-corse.fr. The Letia experiment and consequent research work were supported by the French programme

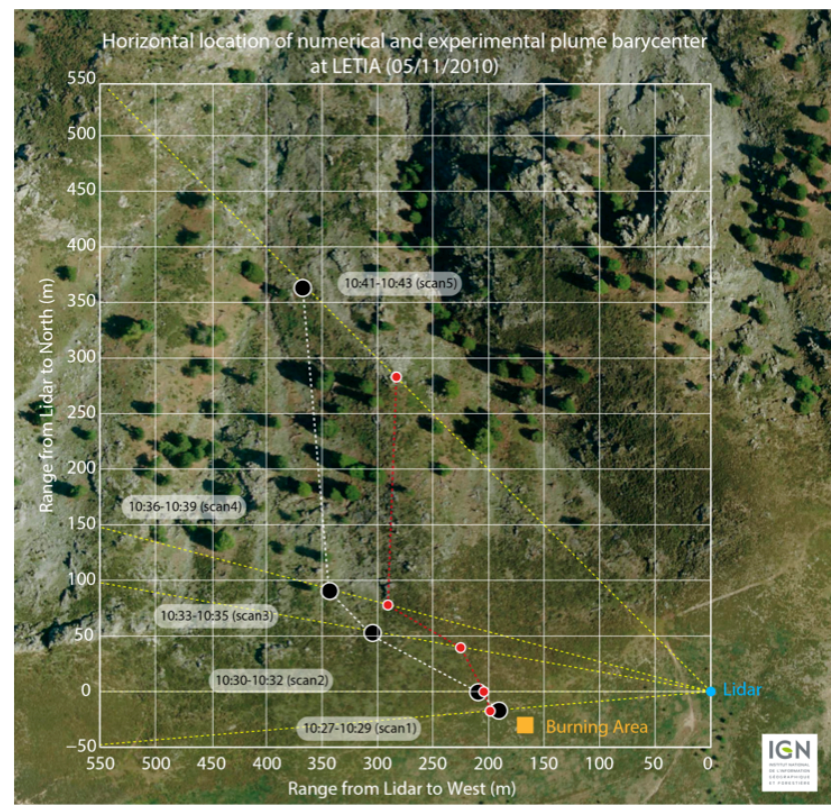

Fig. 11. As Fig. 9 but for horizontal locations.

INSU-LEFE-CHAT and the French ADEME (Agence de l'Environnement et de la maitrise de l'Energie) agency. The computing resources were provided by GENCI-CINES. We thank the MESO-NH support team, project members and anonymous reviewers for the precious help and discussions.

Edited by: B. Cuenot

Reviewed by: two anonymous referees

\section{References}

Alves, C. A., Gonçalves, C., Evtyugina, M., Pio, C. A., Mirante, F., and Puxbaum, H.: Particulate organic compounds emitted from experimental wildland fires in a Mediterranean ecosystem, Atmos. Environ., 44, 2750-2759, 2010.

Alves, C., Vicente, A., Nunes, T., Gonçalves, C., Fernandes, A. P., Mirante, F., Tarelho, L., Sánchez de la Campa, A. M., Querol, X., Caseiro, A., Monteiro, C., Evtyugina, M., and Pio, C.: Summer 2009 wildfires in Portugal: Emission of trace gases and aerosol composition, Atmos. Environ., 45, 641-649, 2011.

Amiridis, V., Balis, D. S., Giannakaki, E., Stohl, A., Kazadzis, S., Koukouli, M. E., and Zanis, P.: Optical characteristics of biomass burning aerosols over Southeastern Europe determined from UVRaman lidar measurements, Atmos. Chem. Phys., 9, 2431-2440, doi:10.5194/acp-9-2431-2009, 2009.

Amiridis, V., Zerefos, C., Kazadzis, S., Gerasopoulos, E., Eleftheratos, K., Vrekoussis, M., Stohl, A., Mamouri, R. E., Kokkalis, P., Papayannis, A., Eleftheriadis, K., Diapouli, E., Keramitsoglou, I., Kontoes, C., Kotroni, V., Lagouvardos, K., Marinou, E., Giannakaki, E., Kostopoulou, E., Giannakopoulos, C., Richter, A., Burrows, J. P., and Mihalopoulos, N.: Impact of the 2009 Attica wild fires on the air quality in urban Athens, Atmos. Environ., 46, 536-544, 2012. 
Anderson, H. E.: Heat transfer and fire spread. USDA Forest Service research paper INT. Intermountain Forest and Range Experiment Station, Forest Service, U.S. Dept. of Agriculture, 1969.

ASTM, D2015-96 "Standard Test Method for Gross Calorific Value of Solid Fuel by the Adiabatic Bomb Calorimeter", 1996.

Baars, H., Ansmann, A., Engelmann, R., and Althausen, D.: Continuous monitoring of the boundary-layer top with lidar, Atmos. Chem. Phys., 8, 7281-7296, doi:10.5194/acp-8-7281-2008, 2008.

Balbi, J. H., Morandini, F., Silvani, X., Filippi, J. B., and Rinieri, F.: A Physical Model for Wildland Fires, Combust. Flame, 156, 2217-2230, 2009.

Barboni, T., Cannac, M., Pasqualini, V., Simeoni, A., Leoni, E., and Chiaramonti, N.: Volatile and semi-volatile organic compounds in smoke exposure of firefighters during prescribed burning in the Mediterranean region, Int. J. Wildland Fire, 19, 606-612, 2010.

Boers, R. and Eloranta, E. W.: Lidar measurement of the atmospheric entrainment zone and the potential temperature jump across the top of the mixed layer, Bound.-Lay. Meteorol., 34, 357-375, 1986.

Bodhaine, B., Wood, N. B., Dutton, E. G., and Slusser, J. R: On Rayleigh optical depth calculations, J. Atmos. Ocean. Tech., 16, 1854-1861, 1999.

Brooks, I. M.: Finding boundary layer top: application of a wavelet covariance transform to lidar back- scatter profiles, J. Atmos. Ocean. Tech., 20, 1092-1105, 2003.

Bucholtz, A.: Rayleigh-scattering calculations for the terrestrial atmosphere, Appl. Optics, 34, 2765-2773, 1995.

Burling, I. R., Yokelson, R. J., Akagi, S. K., Urbanski, S. P., Wold, C. E., Griffith, D. W. T., Johnson, T. J., Reardon, J., and Weise, D. R.: Airborne and ground-based measurements of the trace gases and particles emitted by prescribed fires in the United States, Atmos. Chem. Phys., 11, 12197-12216, doi:10.5194/acp11-12197-2011, 2011.

Burrows, N. D.: Flame residence times and rates of weight loss of eucalypt forest fuel particles, Int. J. Wildland Fire, 10, 137-143, doi:10.1071/WF01005, 2001.

Charland, A. M. and Clements, C. B., Kinematic structure of a wildland fire plume observed by Doppler lidar, J. Geophys. Res.Atmos., 118, 3200-3212, doi:10.1002/jgrd.50308, 2013.

Chu, D. A., Kaufman, Y. J., Zibordi, G., Chern, J. D., Mao, J., Li, C., and Holben, B. N.: Global monitoring of air pollution over land from the Earth observing System-Terra Moderate Resolution Imaging Spectroradiometer (MODIS), J. Geophys. Res., 108, 4661, doi:10.1029/2002JD003179, 2003.

Clark, T. L., Jenkins, M. A., Coen, J. L., and Packham, D. R.: A coupled atmosphere-fire model: convective feedback on fire line dynamics, J. Appl. Meteorol., 35, 875-901, 1996.

Colella, P. and Woodward, P. R.: The Piecewise Parabolic Method (PPM) for GasDynamical Simulations, J. Comput. Phys., 54, 174-201, 1984.

Cohn, S. A. and Angevine, W. M.: Boundary layer height and entrainment zone thickness measured by lidars and wind-profiling radars, J. Appl. Meteorol., 39, 1233-1247, 2000.

Das, S. K., Chiang, C.-W., and Nee, J.-B.: Characteristics of cirrus clouds and its radiative properties based on lidar observation over Chung-Li, Taiwan, Atmos. Res., 93, 723-735, 2009.
Davis, K., Hagelberg, C., and Gamage, N.: An Objective Method for determining atmospheric structure from airborne lidar observations, J. Atmos. Ocean. Tech., 17, 1455-1468, 2000.

Davis, K., Gamage, N., Hagelberg, C., Kiemle, C., LEnschow, D. H., and Sullivan, P. P.: An Objective Method for determining atmospheric structure from airborne lidar observations, J. Atmos. Ocean. Tech., 17, 1455-1468, 2000.

Di Donfrancesco, G., Cairo, F., Buontempo, C., Adriani, A., Viterbini, M., Snels, M., Morbidini, R., Piccolo, F., Cardillo, F., Pommereau, J. P., and Garnier, A.: Balloonborne lidar for cloud physics studies, Appl. Optics, 45, 5701-5708, 2006.

Fernald, F. G.: Analysis of atmospheric lidar observations: Some comments, Appl. Optics, 23, 652-653, 1984.

Fernandes, A. M., Utkin, A. B., Lavrov, A. V., and Vilar, R.: Optimisation of location and number of lidar apparatuses for early forest fire detection in hilly terrain, Fire Safety J., 41, 144-154, 2006.

Filippi, J. B., Bosseur, F., Mari, C., Lac, C., Le Moigne, P., Cuenot, B., Veynante, D., Cariolle, D., and Balbi, J. H.: Coupled Atmosphere-Wildland Fire Modelling, Journal of Advances in Modeling Earth Systems, 1, 11, doi:10.3894/JAMES.2009.1.11, 2009.

Filippi, J. B., Bosseur, F., Pialat, X., Santoni, P.A., Strada, S., Mari, C.: Simulation of coupled fire/atmosphere interaction with the MesoNH-ForeFire models, J. of Combustion, Article ID 540390, 2011.

Flamant, C., Pelon, J., Flamant, P. H., and Durand, P.: Lidar determination of the entrainment zone thickness at the top of the unstable marine atmospheric boundary layer, Bound.-Lay. Meteorol., 83, 247-284, 1997.

Franzi, L., Bratt, J. M., Williams, K. M., and Last, J. A.: Why is particulate matter produced by wildfires toxic to lung macrophages?, Toxicol. Appl. Pharm., 257, 182-188, doi:10.1016/j.taap.2011.09.003, 2011.

Gamage, N. K. K. and Hagelberg, C.: Detection and analysis of microfronts and associated coherent events using localized transforms, J. Atmos. Sci., 50, 750-756, 1993.

Gan, C.-M., Wu, Y., Madhavan, B. L., Gross, B., and Moshary, F.: Application of active optical sensors to probe the vertical structure of the urban boundary layer and assess anomalies in air quality model $\mathrm{PM}_{2.5}$ forecasts, Atmos. Environ., 45, 6613-6621, 2011.

Gross, S., Tesche, M., Freudenthaler, V., Toledano, C., Wiegner, M., Ansmann, A., Althausen, D., and Seefeldner, M.: Characterization of Saharan dust, marine aerosols and a mixture of biomass-burning aerosols and dust by means of multiwavelength depolarization- and Raman measurements during SAMUM-2, Tellus B, 63, 706-724, 2011.

Heese, B. and Wiegner, M.: Vertical aerosol profiles from Raman polarization lidar observations during the dry season AMMA field campaign, J. Geophys. Res., 113, D00C11, doi:10.1029/2007JD009487, 2008.

Hooper, W. P. and Eloranta, E. W.: Lidar measurements of wind in the planetary boundary layer: the method, accuracy and results from joint measurements with radiosonde and kytoon, J. Clim. Appl. Meteorol., 25, 990-1001, 1986.

Hodzic, A., Madronich, S., Bohn, B., Massie, S., Menut, L., and Wiedinmyer, C.: Wildfire particulate matter in Europe during summer 2003: meso-scale modeling of smoke emissions, trans- 
port and radiative effects, Atmos. Chem. Phys., 7, 4043-4064, doi:10.5194/acp-7-4043-2007, 2007.

Kochanski, A., Jenkins, M. A., Krueger, S. K., Mandel, J., Beezley, J. D., and Clements, C. B.: Coupled atmosphere-fire simulations of the FireFlux experiment: Impacts of model resolution on its performance, Ninth Symposium on Fire and Forest Meteorology, 10.2, 8 pp., Palm Springs, CA, 2011.

Kovalev, V. A., Petkov, A., Wold, C., Urbanski, S., and Hao, W. M.: Determination of smoke plume and layer heights using scanning lidar data, Appl. Optics, 48, 5287-5294, 2009.

Lafore, J. P., Stein, J., Asencio, N., Bougeault, P., Ducrocq, V., Duron, J., Fischer, C., Héreil, P., Mascart, P., Masson, V., Pinty, J. P., Redelsperger, J. L., Richard, E., and Vilà-Guerau de Arellano, J.: The Meso-NH Atmospheric Simulation System. Part I: adiabatic formulation and control simulations, Ann. Geophys., 16, 90-109, doi:10.1007/s00585-997-0090-6, 1998.

Langmann, B., Duncan, B., Textor, C., Trentmann, J., and Van der Werf, G. R.: Vegetation fire emissions and their impact on air pollution and climate, Atmos. Environ., 43, 107-116, 2009.

Lavrov, A., Utkin, A. B., Vilar, R., and Fernandes, A.: Application of lidar in ultraviolet, visible and infrared ranges for early forest fire detection, Int. J. Wildland Fire, 12, 159-166, 2003.

Lavrov, A., Utkin, A. B., Vilar, R., and Fernandes, A.: Evaluation of smoke dispersion from forest fire plumes using lidar experiments and modelling, Int. J. Therm. Sci., 45, 848-859, 2006.

Lee, S., Baumann, K., Schauer, J. J., Sheesley, R. J., Naeher, L. P., Meinardi, S., Blake, D. R., Edgerton, E. S., Russell, A. G., and Clements, M.: Gaseous and particulate emissions from prescribed burning in Georgia, Environ. Sci. Technol., 39, 90499056, doi:10.1021/es0515831, 2005.

Leonard, S., Castranova, V., Chen, B. T., Schwegler-Berry, D., Hoover, M., Piacitelli, C., and Gaughan, D. M.: Particle sizedependent radical generation from wildland fire smoke, Toxicology, 236, 103-113, doi:10.1016/j.tox.2007.04.008, 2007.

Mandel, J., Beezley, J. D., and Kochanski, A. K.: Coupled atmosphere-wildland fire modeling with WRF 3.3 and SFIRE 2011, Geosci. Model Dev., 4, 591-610, doi:10.5194/gmd-4-5912011, 2011.

Mao, F., Gong, W., Song, S., and Zhu, Z.: Determination of the boundary layer top from lidar backscatter profiles using a Haar wavelet method over Wuhan, China, Opt. Laser Technol., 49, 343-349, 2013.

Marenco, F., Johnson, B., Turnbull, K., Newman, S., Haywood, J., Webster, H., and Ricketts, H.: Airborne lidar observations of the 2010 Eyjafjallajokull volcanic ash plume, J. Geophys. Res.Atmos., 116, D00U05, doi:10.1029/2011JD016396, 2011.

Matis, I., Ansmann, A., Wandinger, U., and Muller, D.: Unexpectedly high aerosol load in the free troposphere over central Europe in spring/summer 2003, Geophys. Res. Lett., 30, 2178, doi:10.1029/2003GL018442, 2003.

Menut, L., Flamant, C., Pelon, J., and Flamant, P. H.: Urban boundary-layer height determination from lidar measurements over the Paris area, Appl. Optics, 38, 945-954, 1999.

Miranda, A. I.: An integrated numerical system to estimate air quality effects of forest fires, Int. J. Wildland Fire, 13, 217-226, doi:10.1071/WF02047, 2004.

Miranda, A. I., Ferreira, J., Valente, J., Santos, P., Amorin, J. H., and Borrego, C.: Smoke measurements during Gestosa-2002 experimental field fires, Int. J. Wildland fire, 14, 107-116, 2005.
Mona, L., Liu, Z., Mueller, D., Omar, A., Papayannis, A., Pappalardo, G., Sugimoto, N., and Vaughan, M.: Lidar Measurements for Desert Dust Characterization: An Overview, Adv. Meteorol., 2012, 36 pp., doi:10.1155/2012/356265, 2012.

Moro, C.: Détermination des caractéristiques physiques de particules de quelques espèces forestières méditerranéennes, INRA PIF2006-06, 2006.

Omar, A., Winker, D., Kittaka, C., Vaughan, M., Liu, Z., Hu, Y., Trepte, C. R., Rogers, R. R., Ferrare, R. A., Lee, K.-P., Kuehn, R. E., and Hostetler, C. A.: The CALIPSO automated aerosol classification and lidar ratio selection algorithm, J. Atmos. Ocean. Tech., 26, 1994-2014, 2009.

Pahlow, M., Kleissl, J., Parlange, M. B., Ondov, J. O., and Harrison, D.: Atmospheric boundary-layer structure observed during a haze event due to forest-fire smoke, Bound.-Lay. Meteorol., 114, 53-70, 2005.

Pal, S., Behrendt, A., and Wulfmeyer, V.: Elastic-backscatter-lidarbased characterization of the convective boundary layer and investigation of related statistics, Ann. Geophys., 28, 825-847, doi:10.5194/angeo-28-825-2010, 2010.

Phuleria, H. C., Fine, P. M., Zhu, Y., and Sioutas, C.: Air quality impacts of the October 2003 Southern California wildfires, J. Geophys. Res., 110, D07S20, doi:10.1029/2004JD004626, 2005.

Platt, C. M. R.: Remote Sounding of High Clouds. III: Monte Carlo Calculations of Multiple-Scattered Lidar Returns, J. Atmos. Sci., 38, 156-167, 1981.

Raut, J.-C. and Chazette, P.: Assessment of vertically-resolved $\mathrm{PM}_{10}$ from mobile lidar observations, Atmos. Chem. Phys., 9, 8617-8638, doi:10.5194/acp-9-8617-2009, 2009.

Reinhardt, T. E. and Ottmar, R. D.: Baseline measurements of smoke exposure among wildland firefighters, J. Occup. Environ. Hyg., 1, 593-606, 2004.

Royer, P., Chazette, P., Sartelet, K., Zhang, Q. J., Beekmann, M., and Raut, J.-C.: Comparison of lidar-derived $\mathrm{PM}_{10}$ with regional modeling and ground-based observations in the frame of MEGAPOLI experiment, Atmos. Chem. Phys., 11, 1070510726, doi:10.5194/acp-11-10705-2011, 2011.

San-Miguel-Ayanz, J., Schulte, E., Schmuck, G., Camia, A., Strobl, P., Liberta, G., Giovando, C., Boca, R., Sedano, F., Kempeneers, P., McInerney, D., Withmore, C., Santos de Oliveira, S., Rodrigues, M., Durrant, T., Corti, P., Oehler, F., Vilar, L., and Amatulli, G.: Comprehensive Monitoring of Wildfires in Europe: The European Forest Fire Information System (EFFIS), Approaches to Managing Disaster - Assessing Hazards, Emergencies and Disaster Impacts, edited by: Tiefenbacher, J., ISBN: 978-953-51-0294-6, InTech, available at: http://cdn.intechopen.com/pdfs/31818/InTech-comprehensive_ monitoring_of_wildfires_in_europe_the_european_forest_fire_ information_system_effis_.pdf (last access: 6 February 2014), 2012.

Santoni, P. A., Filippi, J. B., Balbi, J. H., and Bosseur, F.: Wildland Fire Behaviour Case Studies and Fuel Models for Landscape-Scale Fire Modeling, J. Combustion, 2011, 12 pp., doi:10.1155/2011/613424, 2011.

Sasano, Y., Shimizu, H., Takeuchi, N., and Okuda, M.: Geometrical form factor in the laser radar equation: an experimental determination, Appl. Optics, 18, 3908-3910, 1979.

Shinozuka, Y., Clarke, A. D., Howell, S. G., Kapustin, V. N., McNaughton, C. S., Zhou, J., and Anderson, B. E.: Aircraft 
profiles of aerosol microphysics and optical properties over North America: Aerosol optical depth and its association with $\mathrm{PM}_{2.5}$ and water uptake, J. Geophys. Res., 112, D12S20, doi:10.1029/2006JD007918, 2007.

Singh, H. B., Cai, C., Kaduwela, A., Weinheimer, A., and Wisthaler, A.: Interactions of fire emissions and urban pollution over California: Ozone formation and air quality simulations, Atmos. Environ., 56, 45-51, doi:10.1016/j.atmosenv.2012.03.046, 2012.

Steyn, D. G., Baldi, M., and Hoff, R. M.: The detection of mixed layer depth and entrainment zone thickness from lidar backscatter profiles, J. Atmos. Ocean. Tech., 16, 953-959, 1999.

Strada, S., Mari, C., Filippi, J. B., and Bosseur, F.: Wildfire and the atmosphere: Modelling the chemical and dynamic interactions at the regional scale, Atmos. Environ., 51, 234-249, 2012.

Tesche, M., Müller, D., Gross, S., Ansmann, A., Althausen, D., Freudenthaler, V., Weinzierl, B., Veira, A., and Petzold, A.: Optical and microphysical properties of smoke over Cape Verde inferred from multiwavelength lidar measurements, Tellus B, 63, 677-694, 2011.

Utkin, A. B., Fernandes, A., Simoes, F., Lavrov, A., and Vilar, R.: Feasibility of forest-fire smoke detection using lidar, Int. J. Wildland Fire, 12, 159-166, 2003.

Vadrevu, K. P., Ellicott, E., Giglio, L., Badarinath, K. V. S., Vermote, E., Justice, C., and Lau, W. K. M.: Vegetation fires in the himalayan region - Aerosol load, black carbon emissions and smoke plume heights, Atmos. Environ., 47 , 241-251, 2012.

van Donkelaar, A., Martin, R. V., and Park, R. J.: Estimating ground-level PM2.5 using aerosol optical depth determined from satellite remote sensing, J. Geophys. Res., 111, D21201, doi:10.1029/2005JD006996, 2006.

Vincente, A., Alves, C., Monteiro, C., Nunes, T., Mirante, F., Cerqueira, Calvo, M. A., and Pio, C.: Organic speciation of aerosols from wildfires in central Portugal during summer 2009, Atmos. Environ., 57, 186-196, 2012.
Wang, J. and Christopher, S. A.: Intercomparison between satellite derived aerosol optical thickness and PM2.5 mass: implications for air quality studies, Geophys. Res. Lett., 30, 2095, doi:10.1029/2003GL018174, 2003.

Wegesser, T. C., Pinkerton, K. E., and Last, J. A.: California Wildfires of 2008: Coarse and Fine Particulate Matter Toxicity, Environ Health Persp., 117, 893-897, 2009.

Weibring, P., Andersson, M., Edner, H., and Svanberg, S.: Remote monitoring of industrial emissions by combination of lidar and plume velocity measurements, Appl. Phys. B, 66, 383-388, 1998.

Winker, D. M., Vaughan, M. A., Omar, A., Hu, Y., Powell, K. A., Liu, Z., Hunt, W. H., and Young, S. A.: Overview of the CALIPSO mission and CALIOP data processing algorithms, J. Atmos. Ocean. Tech., 26, 2310-2323, 2009.

Wold, C. E., Urbanski, S., Kovalev, V., Petkov, A., and Hao, W. M.: Validation of smoke plume rise models using ground based lidar, in: Proceedings of 3rd Fire Behavior and Fuels Conference, edited by: Wade, D. D. and Robinson, M. L., Spokane, WA. Birmingham, AL: International Association of Wildland Fire, 11, 2010.

Yan, B., Zheng, M., Hu, Y. T., Lee, S., Kim, H. K., and Russell, A. G.: Organic composition of carbonaceous aerosols in an aged prescribed fire plume, Atmos. Chem. Phys., 8, 6381-6394, doi:10.5194/acp-8-6381-2008, 2008.

Young, S. A.: Analysis of lidar backscatter profiles in optically thin clouds, Appl. Optics, 34, 7019-7031, 1995. 